\title{
The influence of different combinations of probiotic bacteria and fermentation temperatures on the microbiological and physicochemical characteristics of fermented lactic beverages containing soybean hydrosoluble extract during refrigerated storage
}

\author{
Influência de diferentes combinações de bactérias probióticas e temperaturas de fermentação nas \\ características microbiológicas e físico-químicas de bebidas lácticas fermentadas contendo extrato \\ hidrossolúvel de soja sob estocagem em refrigeração
}

\author{
Ângela Maria FIORENTINI ${ }^{1 \star}$, Cristiano Augusto BALLUS ${ }^{1}$, \\ Marlon Leonardo de OLIVEIRA ${ }^{1}$, Márcio Ferraz CUNHA², Vera Maria KLAJN ${ }^{3}$
}

\begin{abstract}
Lactic beverages containing probiotics were prepared with whole UHT milk, whey of Mozzarella cheese, soybean hydrosoluble extract and sugar. Three formulations were studied, each one containing a different combination of probiotic/starter bacteria, fermented at two different temperatures $\left(37\right.$ and $45^{\circ} \mathrm{C}$ ). The aim of this work was to verify the influence of these variables on the viability of probiotic microorganisms and on the physicochemical stability of lactic beverages during storage under refrigeration ( 21 days at $\left.7^{\circ} \mathrm{C}\right)$. The results indicated that the fermentation temperature had a significant effect on the viability of probiotic bacteria. Counts for Lactobacillus acidophilus were affected by storage time, resulting appropriate after 21 days only for the beverage fermented at $37^{\circ} \mathrm{C}$. Physicochemical parameters did not exhibit drastic variations - proving the stability of formulations during storage. Cells of Bifidobacterium spp. showed high survival ability, probably due to the presence of growth promoters from soybean and cheese whey. The fermentation temperature of $37^{\circ} \mathrm{C}$ allowed counts above the minimum limit for all the studied microorganisms, being preferred to the temperature of $45^{\circ} \mathrm{C}$. The inclusion of soybean hydrosoluble extract, a prebiotics source, resulted in a symbiotic product with more benefits to the health of consumers.

Keywords: Bifidobacterium spp.; Lactobacillus acidophilus; lactic beverages; soybean; probiotics; functional foods.
\end{abstract}

\section{Resumo}

Bebidas lácticas contendo probióticos foram elaboradas com leite UHT integral, soro de queijo Mozarela, extrato hidrossolúvel de soja e açúcar. Três formulações foram estudadas, cada uma contendo diferentes combinações de bactérias probióticas/starters e fermentadas em duas temperaturas $\left(37\right.$ e $45^{\circ} \mathrm{C}$ ). O objetivo foi verificar a influência destas variáveis sobre a viabilidade de microrganismos probióticos e sobre a estabilidade físico-química das bebidas lácticas durante armazenamento sob refrigeração ( 21 dias a $\left.7^{\circ} \mathrm{C}\right)$. Os resultados indicaram que a temperatura de fermentação foi significativa para a viabilidade de bactérias probióticas. A contagem de Lactobacillus acidophilus foi influenciada pelo tempo de armazenamento, resultando adequada ao final de 21 dias apenas para a bebida fermentada a $37^{\circ} \mathrm{C}$. Os parâmetros físico-químicos não variaram drasticamente, demonstrando a estabilidade das formulações durante a estocagem. As células de Bifidobacterium spp. apresentaram elevada capacidade de sobrevivência, possivelmente pela presença de promotores de crescimento provenientes da soja e do soro de queijo. A temperatura de fermentação de $37^{\circ} \mathrm{C}$ possibilitou contagens acima do limite mínimo para todos os microrganismos estudados, sendo preferida ao invés de $45^{\circ} \mathrm{C}$. A inclusão de extrato hidrossolúvel de soja, uma fonte de prebióticos, resultou em um produto simbiótico, com mais vantagens para a saúde do consumidor.

Palavras-chave: Bifidobacterium spp.; Lactobacillus acidophilus; bebidas lácticas; soja; probióticos; alimentos funcionais.

\section{Introduction}

One of the oldest methods used for milk conservation is fermentation, a process that has been used for thousands of years. Nowadays, this process is still of high importance for developing new dairy products, by combining artisanal features and scientific knowledge of different areas (chemistry, biochemistry, microbiology, enzimology, physics and engineering) (TAMIME, 2002; ORDÓÑEZ et al., 2005).
Besides, modern consumers worry about personal health, increasing the demand of foodstuffs capable of supplying not only nutritional aspects, but also healthy benefits, the so-called functional food. A well established market of functional foods is of probiotic yoghurts and probiotic dairy products (MATTILASANDHOLM et al., 2002).

\footnotetext{
Received 9/5/2009

Accepted 4/4/2010 (004190)

Departamento de Biologia e Química, Universidade Regional do Noroeste do Estado do Rio Grande do Sul - UNIJUÍ, RS 344, Km 39, Bairro Timbaúva,

CP 489, CEP 98900-000, Santa Rosa, RS, Brasil, e-mail: angefiore@gmail.edu.br

${ }^{2}$ Departamento de Nutrição, Universidade de Uberaba - UNIUBE, Av. Guilherme Ferreira, 217, Centro, CEP 38010-200, Uberaba, MG, Brasil

${ }^{3}$ Faculdade de Agronomia Eliseu Maciel, Universidade Federal de Pelotas - UFPEL, Campus Capão do Leão, FAEM; Av. Eliseu Maciel, s/n, CEP 96160-000, Capão do Leão, RS, Brasil

${ }^{*}$ Corresponding author
} 
According to FAO (Food and Agriculture Organization of the United Nations) and WHO (World Health Organization), scientific evidences indicate that there is potential for probiotic foods in providing health benefits and that specific strains are safe for human usage (OTIENO; ASHTON; SHAH, 2005). Bifidobacterium spp. and Lactobacillus acidophilus are the most frequently probiotic bacteria employed in the production of probiotic dairy products (GOMES; MALCATA, 1999).

There are several health benefits in consuming probiotics: balancing out temporary instabilities of the intestinal flora; inhibition of the invasion and colonization by pathogenic microorganisms; decrease of the concentration of ammonia, indols and other putrefactive substances; lowering of rotavirusassociated diarrhea in a study with 55 hospitalized children; stimulation of the immune system; inhibition of the growth and division of cancer cells in vitro; cholesterol-lowering effect (probably by deconjugation of bile salts) (MÖLLER; DE VRESE, 2004). However, it is necessary to point out that the regular intake of probiotic viable cells must be of $10^{6} \mathrm{CFU} \cdot \mathrm{g}^{-1}$ of a product in order to provide these beneficial effects (SHAH, 2000; VINDEROLA; BAILO; REINHEIMER, 2000; TALWALKAR; KAILASAPATHY, 2004; ZACARCHENCO; MASSAGUERROIG, 2004; THAMER; PENNA, 2006).

A probiotic strain needs to fulfill some selection criteria to be able to exert its beneficial effects. It is essential to take into account some safety aspects, such as origin (healthy human gastrointestinal tract) and non-pathogenicity. Functional aspects include tolerance to acid and human gastric acid; bile tolerance; adherence to epithelial surfaces and persistence in the human gastrointestinal tract; immunostimulation; antagonistic activity against pathogens; antimutagenic and anticarcinogenic properties. Some technological aspects are good sensory properties; phage resistance; viability during processing; stability in the product and during storage (SANDERS; KLAENHAMMER, 2001; MATTILA-SANDHOLM et al., 2002; CORCORAN et al., 2005; SCHILLINGER; GUIGAS, HOLZAPFEL, 2005; BEGLEY; HILL; GAHAN, 2006; MARAGKOUDAKIS et al., 2006).

Some strains of Streptococcus thermophilus are able to synthesize exopolysaccharides (EPS) that act as natural biothickeners capable of improving texture of fermented foods. This EPS production in situ, during milk fermentation, results in an obvious advantage for the food industry (SVENSSON et al., 2005). Streptococcus thermophilus strains that produce EPS can reduce syneresis and enhance product texture and viscosity. Thus, these types of cultures are commonly used as a substitute for commercial stabilizers in yoghurt manufacture (BROADBENT et al., 2003). Moreover, studies showed that EPS can have beneficial effects on human health, such as cholesterollowering ability, prebiotic effects, immunomodulating and antitumoral activities (RUAS-MADIEDO; REYES-GAVILÁN, 2005).

Some species of Bifidobacterium spp. genus can be stimulated by compounds called prebiotics. Prebiotic is a non-digestible food ingredient that beneficially affects the host by selectively stimulating the growth and/or activity of a limited number of bacteria in the colon. Lactulose, fructooligosaccharides, inulin, resistant starch and soybean oligosaccharides are some examples of prebiotics. Soybean oligosaccharides, as well as raffinose and stachiose, correspond to the flatulence factors, which limit the soybean consumption (RIBEIRO; MORAES; ROIG, 1987; HOU; YU; CHOU, 2000). Since these compounds are not assimilated by humans, they can stimulate and promote the growing of probiotic microorganisms such as bifidobacteria - so being considered a prebiotic (TAMIME; MARSHALL; ROBINSON, 1995; HOU; YU; CHOU, 2000). When a product contains both, probiotics and prebiotics, it is defined as symbiotic (SCHREZENMEIR; DE VRESE, 2001; ITSARANUWAT; SHAL-HADDAD; ROBINSON, 2003).

Soybean hydrosoluble extract showed better sensorial quality after lactic fermentation, when the characteristic beany flavor is masked and, at the same time, the nutritional value is improved (BEHRENS; ROIG; SILVA, 2001; MORAES et al., 2006). In this way, new products, such as soybean cheese and several types of fermented beverages were obtained (CHOU; HOU, 2000). According to Champagne, Gardner and Roy (2005), the fermentation of soybean hydrosoluble extract with probiotic bacteria provide some benefits like reduction of flatulence sugars and improvement of product conservation, as well as contribution to consumer's health. Wang, Yu and Chou (2004) verified a decrease in flatulence oligosaccharides in soybean hydrosoluble extract fermented by mixed cultures of lactic and probiotic bacteria.

For most Brazilian cheese manufacturers, cheese whey is considered a residue being disposed inappropriately in water courses, what can lead to serious contamination problems for aquatic ecosystems (TEBALDI, 2005). Cheese whey represents $85-90 \%$ of the milk volume used for cheese manufacture, retaining about $55 \%$ of the milk nutrients. Thus, the use of cheese whey in lactic beverages becomes a rational way of employing this secondary product with excellent nutritive value (ALMEIDA; BONASSI; ROÇA, 2001). Almost all aminoacid types present in the sweet cheese whey overcome the minimum daily doses of nutrients recommended by the World Health Organization (FAO/WHO) (MACEDO, 1997).

Considering lactic beverages manufacture, the addition of high quantities of cheese whey and soybean hydrosoluble extract reduces product costs. For dairy industries, cheese whey conversion into fermented beverages is one of the most attractive options, when using cheese whey for human consumption, due to the process simplicity - equipment commonly used in milk processing, as well as to the excellent functional properties of whey proteins (MACEDO, 1997).

In the present work, formulations of lactic beverages included milk, soybean hydrosoluble extract (soymilk) and cheese whey from Mozzarella manufacture. The aim of this study was to elaborate fermented lactic beverages (using dairy and non-dairy substrates) with different combinations of probiotic/ starter bacteria and fermentation temperatures in order to verify the influence of these combinations on the viability of probiotic microorganisms and on the physicochemical stability of lactic beverages during refrigerated storage. 


\section{Materials and methods}

\subsection{Starter and probiotic cultures}

Lyophilized cultures of Lactobacillus acidophilus La-5, Bifidobacterium bifidum BB-12 and ABT-4 (containing Streptococcus thermophilus, Lactobacillus acidophilus, Bifidobacterium lactis and Bifidobacterium bifidum) were purchased from Christian Hansen Ltda. (Valinhos, Sao Paulo, Brazil). Cultures of Bifidobacterium lactis BL LYO and Streptococcus thermophilus EPS producing strain were kindly provided by Danisco (Dangé-Saint-Romain, France) and ISP Brasil (Cabreuva, Sao Paulo, Brazil), respectively. Each culture was aseptically diluted in $240 \mathrm{~mL}$ of sterile UHT milk (Elegê, Rio Grande do Sul, Brazil), which was subsequently divided into twelve equal portions of $20 \mathrm{~mL}$. The cultures were then stored at $-80{ }^{\circ} \mathrm{C}$ until use.

\subsection{Soybean hydrosoluble extract (soymilk) and cheese whey powder}

The soybean hydrosoluble extract was obtained according to the procedure described by Prudencio and Benedet (1999), using organic soybean (Glycine max) purchased at local supermarkets. Whey powder from Mozzarella cheese, supplied by a local dairy industry (Elegê, Rio Grande do Sul, Brazil), was dissolved in water at a ratio of 1:12 (whey powder:water), immediately before use.

\subsection{Lactic beverage preparation and storage}

Preliminary tests were performed in our laboratory to determine the most appropriate concentration of each substrate in lactic beverage formulation, considering physicochemical and sensorial properties (data not published yet).

Lactic beverages were prepared mixing $40 \%$ of UHT whole milk (Elegê, Rio Grande do Sul, Brazil), 30\% of Mozzarella cheese whey, $30 \%$ of soybean hydrosoluble extract and $10 \%$ of sugar (sucrose) in a pilot-scale yoghurt fermented (Tecnoinox, Rio Grande do Sul, Brazil). Then, this mixture was heat-treated ( $90^{\circ} \mathrm{C}$ for 5 minutes) and subsequently cooled to fermentation temperature. Two different temperatures were evaluated: 37 and $45{ }^{\circ} \mathrm{C}$. An inoculum of $20 \mathrm{~mL}$ of each culture (according to the formulation) was used to inoculate $6 \mathrm{~L}$ of lactic beverage, and the incubation was carried out until $\mathrm{pH}$ reached 4.5-5.0. After the end of fermentation, the lactic beverages were cooled to $20{ }^{\circ} \mathrm{C}$, homogenized and distributed into $1 \mathrm{~L}$ high-density polyethylene plastic bottles. These bottles were then stored at $7^{\circ} \mathrm{C} \pm 1{ }^{\circ} \mathrm{C}$, for 21 days. Figure 1 presents a flowchart for the lactic beverage preparation. Three formulations were studied: BL1 (fermented only by probiotic bacteria: Lactobacillus acidophilus, Bifidobacterium lactis and Bifidobacterium bifidum); BL2 (fermented by starter and probiotic bacteria: Streptococcus thermophilus, Lactobacillus acidophilus, Bifidobacterium lactis and Bifidobacterium bifidum); and BL3 (fermented by Streptococcus thermophilus EPS producing strain with probiotic bacteria: Lactobacillus acidophilus, Bifidobacterium lactis and Bifidobacterium bifidum). BL2 formulation was inoculated with ABT-4, while BL1 and BL3 were inoculated with the combination of single bacteria cultures, according to each formulation. Counts of viable lactic bacteria and physicochemical analysis were carried out at $0,7,14$ and 21 days of refrigerated storage. The analyses of 0 day were carried out after overnight cold storage of the lactic beverages.

\subsection{Physicochemical analysis}

Samples of each lactic beverage formulation were submitted to the following physicochemical analyses:

- $p H$, by using a digital pHmeter (Digimed, model DM-20, Brazil) with a combined glass electrode and temperature probe, previously calibrated with fresh $\mathrm{pH} 4.0$ and 7.0 standard buffers;

UHT Milk (40\%) + cheese whey powder $(30 \%)+$ soybean hidrosoluble extract $(30 \%)+$ sucrose $(10 \%)$

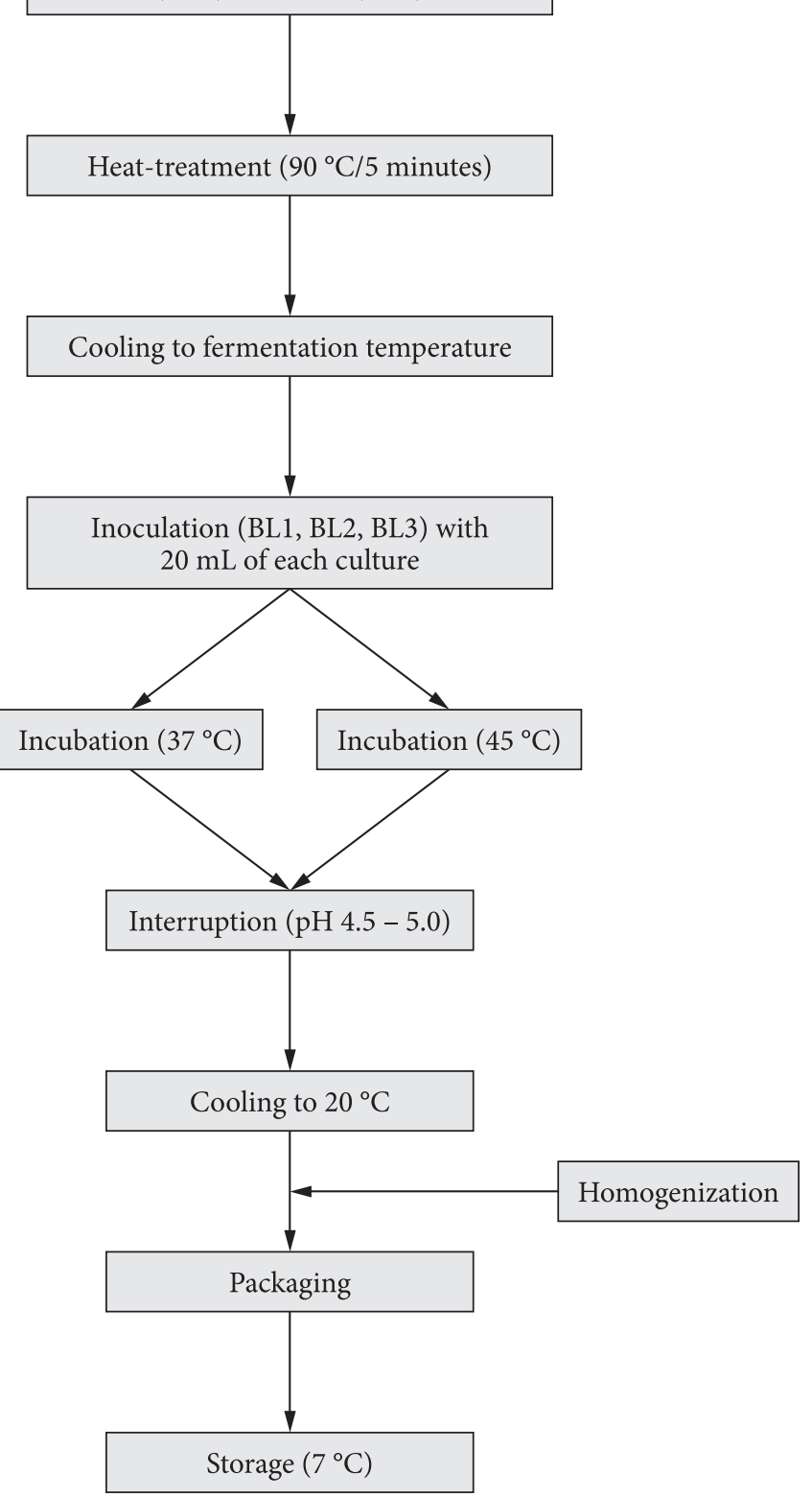

Figure 1. Flowchart for lactic beverage elaboration. 
- Titratable acidity (expressed as lactic acid content), by an acid-basis reaction between lactic acid and $\mathrm{NaOH} 0.111 \mathrm{~N}$, with the end point visualization related to color change of phenolphthalein indicator (INSTITUTO ADOLFO LUTZ, 1985);

- Proteolysis, by measuring liberated tyrosine (amino acid), according to spectrophotometric method described by Almeida, Bonassi and Roça (2001). In this method, 5 $\mathrm{mL}$ of lactic beverage samples were added to a test tube, and subsequently mixed with $10 \mathrm{~mL}$ of trichloroacetic acid $0,72 \mathrm{~N}$ and $1 \mathrm{~mL}$ of distilled water; after $10 \mathrm{~min}$, the mixture was filtered, and $5 \mathrm{~mL}$ of the permeate was added to a $50 \mathrm{~mL}$ volumetric flask; then, $10 \mathrm{~mL}$ of sodium carbonate/sodium hexametaphosphate solution (at $40{ }^{\circ} \mathrm{C}$ ) and $3 \mathrm{~mL}$ of Folin-Ciocalteu phenol reagent (1:2 aqueous solution) were added; absorbance readings at $650 \mathrm{~nm}$ were performed using a double-beam UVVisible Spectrophotometer (Perkin Elmer, model Lambda 2S, USA), after 5 minutes; the quantification of liberated tyrosine was done from the standard curve obtained using tyrosine solutions with pre-determined concentrations; and

- Syneresis, according to Hashimoto and Antunes (1995), in which $100 \mathrm{~mL}$ of lactic beverage sample were added to a 100 mesh cloth, supported by a funnel inserted at a graduated cylinder, used to collect the permeate. This set was kept at $10^{\circ} \mathrm{C}$ for 2 hours, and then, the collected permeate was read as syneresis in $100 \mathrm{~mL}$ of sample.

All chemicals used were of analytical grade, and determinations were made in duplicate.

\subsection{Enumeration of viable lactic bacteria}

Lactic beverages samples $(1 \mathrm{~mL})$ were decimally diluted in test tubes with $9 \mathrm{~mL}$ of sterile peptone water $(0.1 \% \mathrm{w} / \mathrm{v})$ (Acumedia, USA), and $0.1 \mathrm{~mL}$ aliquot was placed over each culture media.

- For Streptococcus thermophilus selective counts, the ST (Streptococcus thermophilus) medium with aerobic incubation at $30{ }^{\circ} \mathrm{C}$ for 48 hours (DAVE; SHAH, 1996; modified by ZACARCHENCO, 2004) was used;

- For selective enumeration of Lactobacillus acidophilus, MRS (De Man, Rogosa \& Sharp) agar (Acumedia, USA) added with $0.15 \%(w / v)$ of bile (Vetec, Brazil) - (BileMRS) - and aerobic incubation at $37^{\circ} \mathrm{C}$ for 72 hours (VINDEROLA; REINHEIMER, 1999; ZACARCHENCO, 2004) was employed;

- Selective enumeration of Bifidobacterium spp. was performed in MRS agar (Acumedia, USA) added with 0.5 g.. $\mathrm{L}^{-1}$ of lithium chloride (Ecibra, Brazil) and 0.75 g.L. $\mathrm{L}^{-1}$ of sodium propionate (Sigma, Germany) - Lithium ChlorideSodium Propionate Agar (Agar LP-MRS), with incubation in anaerobic conditions (Anaerocult A, Merck, Germany) at $37^{\circ} \mathrm{C}$ for 72 hours (LAPIERRE; UNDELAND; COX, 1992; modified by ZACARCHENCO, 2004).
Colonies identification was initially checked through Gram stain, and all counts were realized in duplicate.

\subsection{Experimental design and statistical analysis}

The experimental design was completely randomized, with factorial arrangement $3 \times 2 \times 4$ (formulations $\times$ fermentation temperatures $\times$ storage time). The experiment was carried out in triplicate, resulting in 72 experimental units. Data were analyzed using Statistica 6.0 software (StatSoft Inc., USA, 2001), applying ANOVA with $95 \%$ confidence level $(P<0.05)$. Differences between media were detected by Tukey's test.

\section{Results and discussion}

The mathematical model for a $3 \times 2 \times 4$ factorial arrangement at a completely randomized design with three replicates is (Equation 1):

$\mathrm{Y}_{\mathrm{ijkm}}=\mu+\mathrm{F}_{\mathrm{i}}+\mathrm{T}_{\mathrm{j}}+\mathrm{S}_{\mathrm{k}}+(\mathrm{FT})_{\mathrm{ij}}+(\mathrm{FS})_{\mathrm{ik}}+(\mathrm{TS})_{\mathrm{jk}}+(\mathrm{FTS})_{\mathrm{ijk}}+\mathrm{E}_{\mathrm{ijkm}}$ (i $=1,2,3 ; \mathrm{j}=1,2 ; \mathrm{k}=1,2,3,4 ; \mathrm{m}=1,2,3)$,

where:

$\mathrm{Y}_{\mathrm{ijkm}}=$ observed value for the variable that received level $\mathrm{i}$ of factor $\mathrm{F}$, level $\mathrm{j}$ of factor $\mathrm{T}$, and level $\mathrm{k}$ of factor $\mathrm{S}$, in the $\mathrm{m}$ replicate;

$\mu=$ experiment general medium; $F_{i}=$ effect of formulation $i$

$T_{j}=$ effect of fermentation temperature $j ;$

$\mathrm{S}_{\mathrm{k}}=$ effect of storage time $\mathrm{k}$;

$(\mathrm{FT})_{\mathrm{ij}}=$ effect of interaction between formulation $\mathrm{i}$ and fermentation temperature $\mathrm{j}$;

$(\mathrm{FS})_{\mathrm{ik}}=$ effect of interaction between formulation $\mathrm{i}$ and storage time $\mathrm{k}$;

$(\mathrm{TS})_{\mathrm{i} \mathrm{k}}=$ effect of interaction between fermentation emperature $\mathrm{j}$ and storage time $\mathrm{k}$;

$(\mathrm{FTS})_{\mathrm{ijk}}=$ effect of interaction among formulation $\mathrm{i}$, fermentation temperature $\mathrm{j}$ and storage time $\mathrm{k}$; and

$\mathrm{E}_{\mathrm{i} \mathrm{kmm}}=$ experimental error associated with each observation.

To investigate violations of the basic assumptions of ANOVA and model adequacy, an examination of residuals was performed. The normality of residuals assumption was checked by the construction of a normal probability plot (if the error distribution is normal, this plot will be similar to a straight line), while the assumption of variances homogeneity was verified by the construction of residuals versus predicted values plot (this plot should not reveal any obvious pattern), both for each dependent variable (MONTGOMERY, 2000). Figure 2 shows four plots obtained for some dependent variables. Microbiological counts did not satisfy normality of residuals and variances homogeneity assumptions, and then, data of the counts were submitted to a square root transformation, and ANOVA was run on the transformed data. Data of proteolysis did not violate ANOVA assumptions when expressed in mg. $\mathrm{L}^{-1}$.

Changes on physicochemical parameters throughout refrigerated storage are shown in Figure 3. 

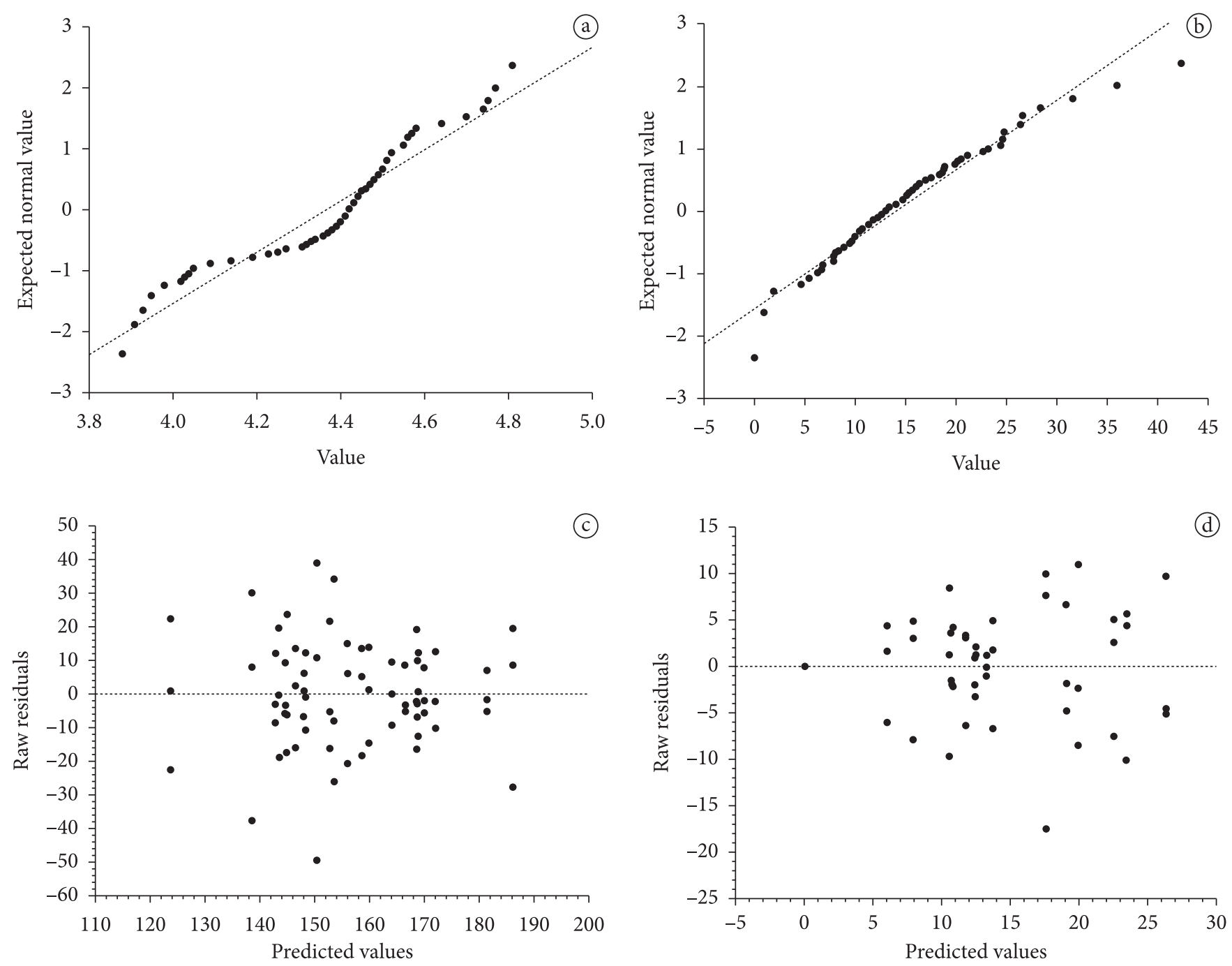

Figure 2. Normal probability ( $\mathrm{a}$ and b) and residuals versus predicted values ( $\mathrm{c}$ and d) plots: a) pH; b) Bifidobacterium spp. counts (after square root transformation); c) proteolysis (values expressed in $\mathrm{mg. \textrm {L } ^ { - 1 }}$ ); and d) Streptococcus thermophilus counts (after square root transformation).

The different formulations had a significant effect $(\mathrm{P}=0.00325)$ on $\mathrm{pH}$ value, as it can be seen in Table 1 . The medium for BL3 was statistically different from the ones for BL2 and BL1. However, this difference could be attributed to the difficulty in stopping fermentation always at the same $\mathrm{pH}$ value. Since the final $\mathrm{pH}$ varied among the replicates and treatments, this could lead to a different decrease in $\mathrm{pH}$ during the first overnight cold storage.

The titratable acidity was affected by the formulations $(\mathrm{P}=0.0195)$. The medium for BL1 was statistically different from BL2, while BL2 and BL3 have not differed significantly (Table 1). BL1 formulation contained only probiotic bacteria and, being Bifidobacterium spp. heterofermentative microorganisms, in the absence of $S$. thermophilus they were free to produce lactic and acetic acids. This could explain the higher acidity level of BL1 when compared to the other two formulations, which contain S. thermophilus. According to Ordóñez et al. (2005), the use of Bifidobacterium spp. with a starter culture such as S. thermophilus, leads to a lower production of acetic acid by the probiotic bacteria. Therefore, the acidity of the product obtained by this combination would be lower, as observed in the present study. Almeida, Bonassi and Roça (2001) also reported that, in treatments using probiotic bacteria, the acidity was slightly higher at the end of storage.

Formulations, fermentation temperature, and interaction formulation versus fermentation temperature had significant effect $(\mathrm{P}<0.01)$ on syneresis. The medium of syneresis for BL3 was statistically different from BL2 and BL1. Besides, fermentation temperature affected syneresis, since at $37^{\circ} \mathrm{C}$ the medium was $80.68 \mathrm{~mL}$, and at $45^{\circ} \mathrm{C}$ the medium reached $74.63 \mathrm{~mL}$. Table 1 presents media values for formulations and for interaction between formulations versus fermentation temperature. For the last one, $\mathrm{BL} 3\left(37^{\circ} \mathrm{C}\right)$ medium value for syneresis was statistically different from all the other combinations.

The difference between BL3 $\left(37^{\circ} \mathrm{C}\right)$ and the other combinations, as well as the difference between BL3 and the other two formulations, could be explained by an experimental error detected during one of the replicates of BL3 $\left(37^{\circ} \mathrm{C}\right)$ elaboration, where the final $\mathrm{pH}$ obtained was 4.80 . In $\mathrm{pH}$ values 

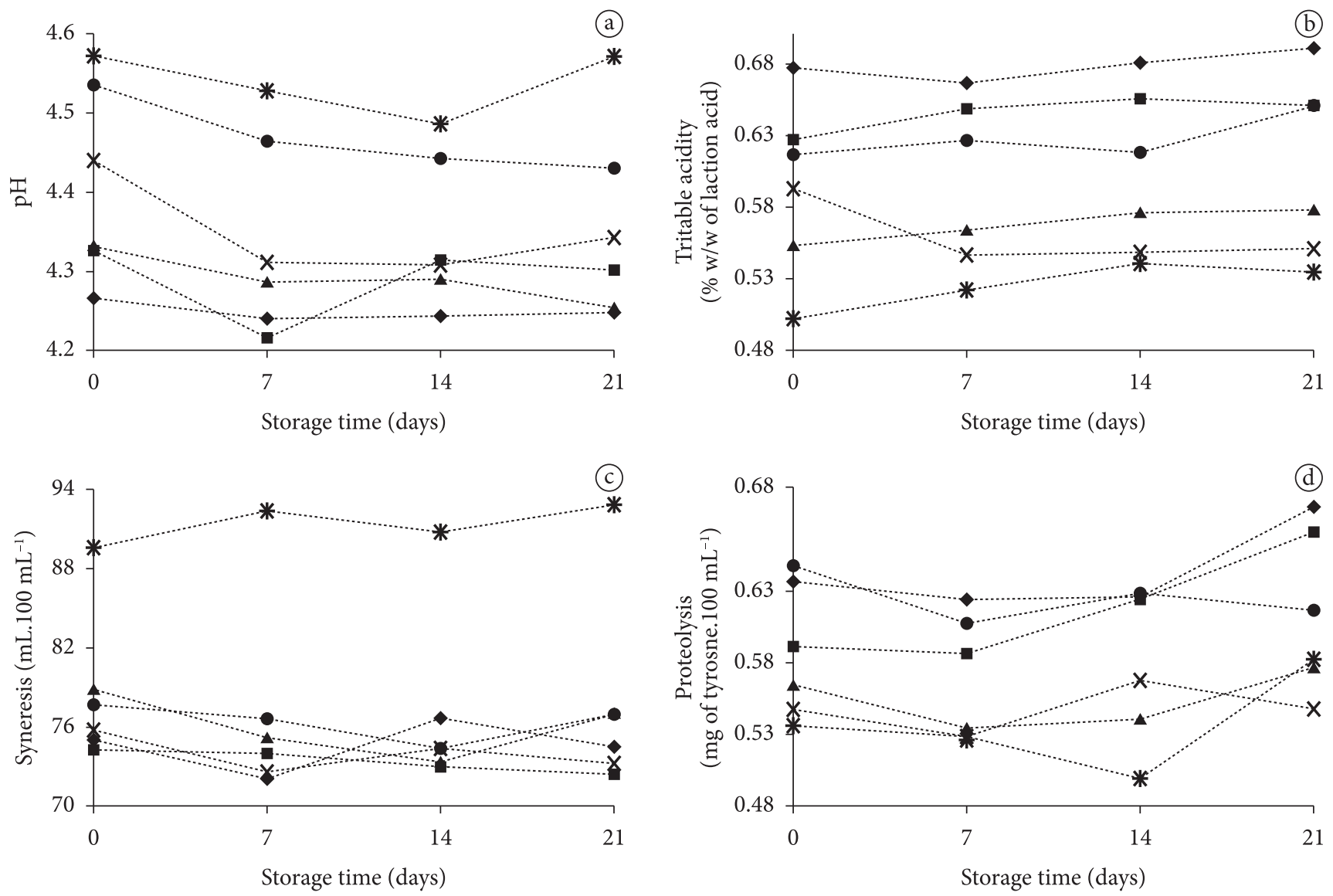

$$
\operatorname{BL} 1\left(37^{\circ} \mathrm{C}\right) \quad \cdots \cdots \operatorname{BL} 1\left(45^{\circ} \mathrm{C}\right) \quad \cdots \cdots \cdots
$$

Figure 3. Variations on the physicochemical parameters during refrigerated storage of dairy beverages (values are media of three experiment replicates): a) $\mathrm{pH}$; b) titratable acidity; c) syneresis; and d) proteolysis.

Table 1. Medium results for physicochemical parameters*.

\begin{tabular}{|c|c|c|c|c|}
\hline Formulation & $\mathrm{pH}$ & $\begin{array}{c}\text { Tritatable acidity } \\
\text { (\% w/w lactic acid) }\end{array}$ & $\begin{array}{c}\text { Syneresis } \\
\left(\mathrm{mL} .100 \mathrm{~mL}^{-1}\right)\end{array}$ & $\begin{array}{c}\text { Proteolysis } \\
\left(\mathrm{mg} \cdot \mathrm{L}^{-1}\right)\end{array}$ \\
\hline BL1 & $4.27^{\mathrm{b}}$ & $0.6616^{\mathrm{a}}$ & $74.04^{\mathrm{b}}$ & $170.59^{\mathrm{a}}$ \\
\hline BL2 & $4.32^{\mathrm{b}}$ & $0.5637^{\mathrm{b}}$ & $75.08^{\mathrm{b}}$ & $149.11^{\mathrm{b}}$ \\
\hline BL3 & $4.50^{\mathrm{a}}$ & $0.5762^{\mathrm{ab}}$ & $83.85^{\mathrm{a}}$ & $150.26^{\mathrm{b}}$ \\
\hline \multicolumn{2}{|c|}{ Formulation $\times$ Temperature } & \multicolumn{2}{|c|}{$\begin{array}{c}\text { Syneresis } \\
\left(\mathrm{mL} .100 \mathrm{~mL}^{-1}\right)\end{array}$} & $\begin{array}{l}\text { Proteolysis } \\
\left(\mathrm{mg} \cdot \mathrm{L}^{-1}\right)\end{array}$ \\
\hline \multicolumn{2}{|c|}{$\mathrm{BL} 3\left(37^{\circ} \mathrm{C}\right)$} & \multicolumn{2}{|c|}{$91.29^{\mathrm{a}}$} & $137.71^{\mathrm{c}}$ \\
\hline \multicolumn{2}{|c|}{$\mathrm{BL} 3\left(45^{\circ} \mathrm{C}\right)$} & \multicolumn{2}{|c|}{$76.42^{\mathrm{b}}$} & $162.81^{\mathrm{ab}}$ \\
\hline \multicolumn{2}{|c|}{$\mathrm{BL} 2\left(37^{\circ} \mathrm{C}\right)$} & \multicolumn{2}{|c|}{$76.13^{\mathrm{b}}$} & $150.03^{\mathrm{bc}}$ \\
\hline \multicolumn{2}{|c|}{$\operatorname{BL} 1\left(37^{\circ} \mathrm{C}\right)$} & \multicolumn{2}{|c|}{$74.63^{\mathrm{b}}$} & $174.01^{\mathrm{a}}$ \\
\hline \multicolumn{2}{|c|}{$\mathrm{BL} 2\left(45^{\circ} \mathrm{C}\right)$} & \multicolumn{2}{|c|}{$74.04^{\mathrm{b}}$} & $148.18^{\mathrm{bc}}$ \\
\hline \multicolumn{2}{|c|}{$\operatorname{BL} 1\left(45^{\circ} \mathrm{C}\right)$} & \multicolumn{2}{|c|}{$73.46^{\mathrm{b}}$} & $167.16^{\mathrm{ab}}$ \\
\hline
\end{tabular}

${ }^{*}$ Media followed by different letters are significantly different by Tukey's test at $95 \%$ confidence level

higher than 4.6, there was not an adequate formation of the coagulum, resulting in an increase of syneresis (THAMER; PENNA, 2006). Moreover, BL3 is the formulation that contains $S$. thermophilus EPS producing strain and, theoretically, syneresis in this formulation should be lower than in the other two formulations. However, even BL3 $\left(45^{\circ} \mathrm{C}\right)$ did not exhibit significant difference in syneresis when compared to BL1 and BL2. So, some of the factors that affect EPS production by the lactic acid bacteria strain were probably not favorable, as well as the medium composition (carbon/nitrogen source) or culture 
conditions ( $\mathrm{pH}$, temperature, $\mathrm{O}_{2}$ concentration) (RIBEIRO; MORAES; ROIG, 2005). Considering the fermentation temperature, it appears reasonable to assume that the media were different as a result of the higher syneresis obtained for BL3 $\left(37^{\circ} \mathrm{C}\right)$, which increased the medium for the fermentation temperature of $37^{\circ} \mathrm{C}$.

Proteolysis was affected by formulations $(\mathrm{P}<0.01)$ and by the interaction formulation $\times$ fermentation temperature $(\mathrm{P}=0.0122)$ (Table 1). The medium for BL1 was statistically different from BL3 and BL2 due to the fact that probiotic bacteria are more proteolytic than starter culture. Similar results were reported by Almeida et al. (2001) and Donkor et al. (2006). For BL3, fermentation temperature affected proteolysis, with the medium at $45^{\circ} \mathrm{C}\left(162.81 \mathrm{mg} . \mathrm{L}^{-1}\right)$ higher than at $37^{\circ} \mathrm{C}\left(137.71 \mathrm{mg} . \mathrm{L}^{-1}\right)$. It is likely that $S$. thermophilus EPS producing strain has a higher proteolytic activity at its optimum growth temperature.

Variations on counts of viable lactic bacteria, throughout the entire refrigerated storage, are shown in Figure 4.

For Streptococcus thermophilus counts, carried out just in BL2 and BL3 formulations, there was a significant difference between formulations $(\mathrm{P}<0.01)$. It is necessary to consider that the data of counts of viable lactic bacteria were submitted to square root transformation, and ANOVA was carried out using the transformed data. The medium for BL2 $\left(19188.0=3.68 \times 10^{8}\right.$ CFU.mL $\left.{ }^{-1}\right)$ was higher than for BL3 $\left(10728.0=1.15 \times 10^{8}\right.$ CFU.mL $\left.{ }^{-1}\right)$. Some studies suggested that probiotic bacteria proved to have higher inhibitory activity toward starter cultures than the opposite. All Bifidobacterium spp. strains tested by Vinderola; Mocchiutti; Reinheimer (2002) inhibited the growth of S. thermophilus. Thus, the lower counts of S. thermophilus obtained for BL3 could be related to an antagonism between $S$. thermophilus EPS producing strain and probiotic bacteria.

Viability of Lactobacillus acidophilus was affected by formulations, fermentation temperature, and storage time and by the interaction formulation $\times$ temperature (Table 2). Regarding the formulations, medium of BL1 was statistically different $(P=0.0133)$ from BL2, but not different from BL3. BL1 also presented the highest proteolysis, and the higher amount of released amino acids enhanced the survival of probiotic bacteria, and in this case, improved the survival of $L$. acidophilus (DONKOR et al., 2006). For the two fermentation temperatures studied, $37^{\circ} \mathrm{C}$ was significantly $(\mathrm{P}<0.01)$ more favorable to $L$. acidophilus when compared to $45^{\circ} \mathrm{C}$. This result is in agreement with those obtained by Akin and Güler-Akin (2005) and Mortazavian et al. (2006). Furthermore, it has been reported that the optimum growth temperature of probiotics is approximately $37^{\circ} \mathrm{C}$ (ORDÓÑEZ et al., 2005). The media for the significant effect $(\mathrm{P}<0.01)$ of storage time are also shown in Table 2.

During refrigerated storage, counts of L. acidophilus decreased in approximately $1 \log$ after the first 7 days, and continued to reduce until the end of storage ( 21 days), with final counts remaining above the suggested levels $\left(10^{6} \mathrm{CFU} \cdot \mathrm{mL}^{-1}\right)$. On the other hand, just the formulations fermented at $37^{\circ} \mathrm{C}$ exhibited counting above $10^{6} \mathrm{CFU} \cdot \mathrm{mL}^{-1}$ after 21 days of storage (Figure 4b). Vinderola; Bailo; Reinheimer (2000) and Akin and
Güler-Akin (2005) also concluded that L. acidophilus were the most sensitive probiotic bacteria during refrigerated storage. Interaction between formulation and fermentation temperature was significant $(\mathrm{P}=0.0161)$ to the viability of $L$. acidophilus, with the highest counts obtained for BL1 fermented at $37^{\circ} \mathrm{C}$.

According to Mattila-Sandholm et al. (2002), packaging materials and storage conditions are important factors for the quality of products containing probiotic microorganisms.
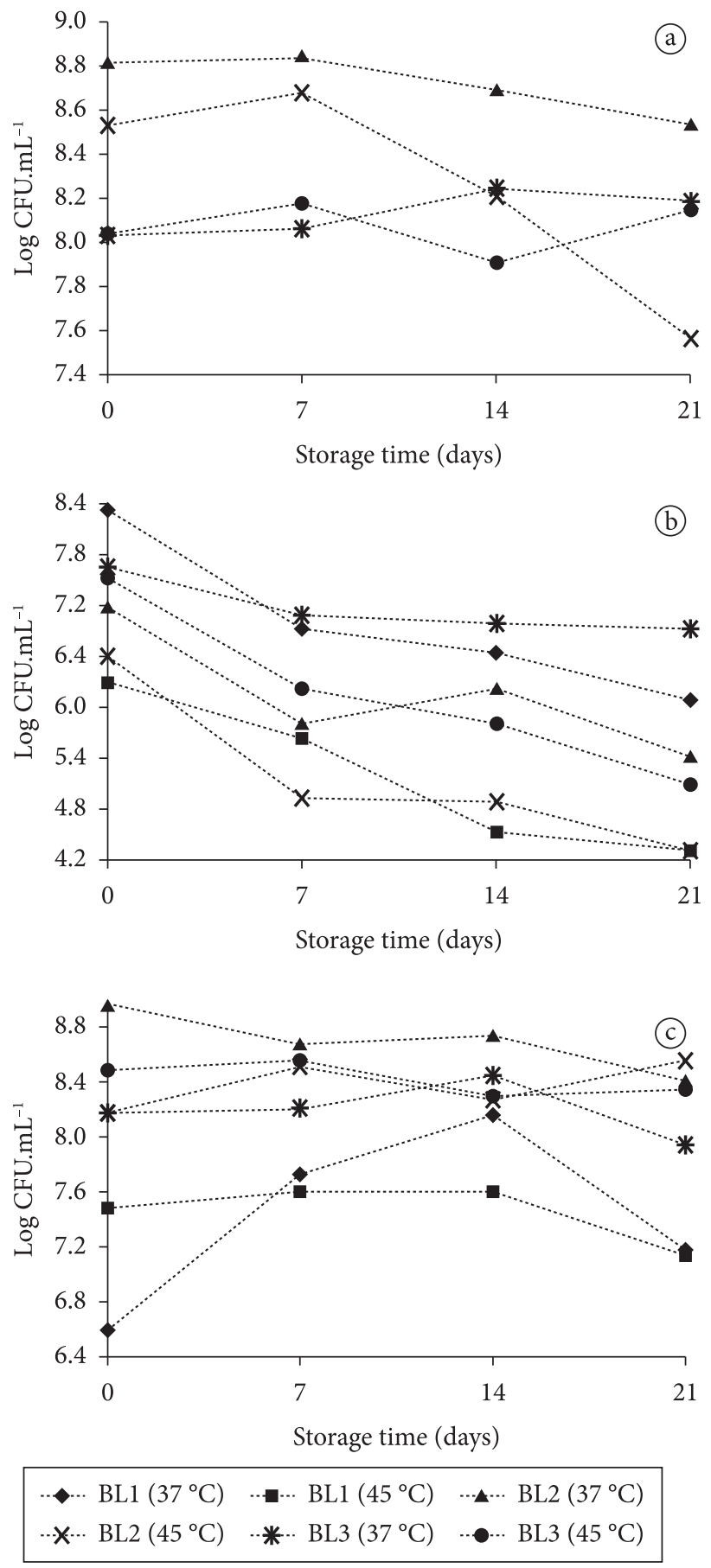

Figure 4. Variations on the counts of viable lactic bacteria during refrigerated storage of dairy beverages (values are avarage of three experiment replicates): a) Streptococcus thermophilus; b) Lactobacillus acidophilus; and c) Bifidobacterium spp. 
In the present study, plastic bottles were used (High-density Polyethylene - HDPE) for lactic beverages packaging, the same material used for products of regular industries. However, this material has high oxygen permeability. The strains generally used in probiotic products are anaerobic or microaerophilic, so that exposure to dissolved oxygen during processing and storage is highly detrimental to L. acidophilus and Bifidobacterium spp.

In general, once strictly anaerobic, Bifidobacterium spp. are more sensitive to oxygen than L. acidophilus, but this sensitivity is exclusively dependent on the specific strain used (TALWALKAR; KAILASAPATHY, 2003). Dave and Shah (1997) studied the behavior of $L$. acidophilus in yogurts bottled in glass and high-density polyethylene containers for 35 days. The level of dissolved oxygen in the glass containers remained low, whereas oxygen levels in the plastic packages increased significantly.

Wang, Yu and Chou (2004) monitored viable cell counts of S. thermophilus and B. bifidum in fermented soy milk bottled in (1) glass containers, (2) polyethylene packages containing an oxygen absorber and a desiccant, and (3) laminated bags (nylon/aluminum/polypropylene); stored at 4 and $25^{\circ} \mathrm{C}$. The total microbial population was found to decrease with storage time independently of the packaging material used. The product stored at $25^{\circ} \mathrm{C}$ exhibited higher values compared to the product kept at $4{ }^{\circ} \mathrm{C}$, with the differences being directly proportional to the temperature difference. They verified that the higher the permeability of the packaging material, the lower the number of viable bacterial cells. The use of appropriate packaging materials and systems is of great importance to preserve manufacturing process improvements and to ensure good acceptance by consumers.

The results for Bifidobacterium spp. counts are showed in Table 3. The effect of formulations was statistically significant $(\mathrm{P}<0.01)$ for Bifidobacterium spp. counts.

The highest media for viable cells were achieved by BL2 and BL3, which did not differ significantly, while BL1

Table 2. Media of L. acidophilus counts.

\begin{tabular}{|c|c|c|}
\hline Formulation & Mean $^{*}$ & Mean $^{* *}$ \\
\hline BL1 & $4185.0^{\mathrm{a}}$ & $1.75 \times 10^{7}$ \\
\hline BL3 & $3580.5^{\mathrm{ab}}$ & $1.28 \times 10^{7}$ \\
\hline BL2 & $1689.4^{\mathrm{b}}$ & $2.85 \times 10^{6}$ \\
\hline Temperature $\left({ }^{\circ} \mathrm{C}\right)$ & Mean $^{*}$ & Mean $^{* *}$ \\
\hline 37 & $4660.8^{\mathrm{a}}$ & $2.17 \times 10^{7}$ \\
\hline 45 & $1642.5^{\mathrm{b}}$ & $2.70 \times 10^{6}$ \\
\hline Storage time (days) & Mean $^{*}$ & Mean $^{* *}$ \\
\hline 0 & $6712.8^{\mathrm{a}}$ & $4.51 \times 10^{7}$ \\
\hline 7 & $2434.2^{\mathrm{b}}$ & $5.93 \times 10^{6}$ \\
\hline 14 & $2159.1^{\mathrm{b}}$ & $4.66 \times 10^{6}$ \\
\hline 21 & $1300.5^{\mathrm{b}}$ & $1.69 \times 10^{6}$ \\
\hline Formulation $\times$ Temperature & Mean $^{*}$ & Mean $^{* *}$ \\
\hline $\operatorname{BL} 1\left(37^{\circ} \mathrm{C}\right)$ & $7030.4^{\mathrm{a}}$ & $4.94 \times 10^{7}$ \\
\hline $\mathrm{BL} 3\left(37^{\circ} \mathrm{C}\right)$ & $4943.7^{\mathrm{ab}}$ & $2.44 \times 10^{7}$ \\
\hline $\mathrm{BL} 3\left(45^{\circ} \mathrm{C}\right)$ & $2217.3^{b c}$ & $4.92 \times 10^{6}$ \\
\hline $\mathrm{BL} 2\left(37^{\circ} \mathrm{C}\right)$ & $2008.4^{\mathrm{bc}}$ & $4.03 \times 10^{6}$ \\
\hline BL2 $\left(45^{\circ} \mathrm{C}\right)$ & $1370.5^{c}$ & $1.88 \times 10^{6}$ \\
\hline $\mathrm{BL} 1\left(45^{\circ} \mathrm{C}\right)$ & $1339.5^{\mathrm{c}}$ & $1.79 \times 10^{6}$ \\
\hline
\end{tabular}

${ }^{*}$ Media for square root transformed data; media followed by different letters are significantly different by Tukey’s test at $95 \% .{ }^{* *}$ Correspondent media at CFU.mL ${ }^{-1}$.

Table 3. Media for Bifidobacterium spp. counts.

\begin{tabular}{ccc}
\hline Formulation & Mean $^{*}$ & Mean $^{* *}$ \\
\hline BL2 & $18631.0^{\mathrm{a}}$ & $3.47 \times 10^{8}$ \\
BL3 & $15408.0^{\mathrm{a}}$ & $2.37 \times 10^{8}$ \\
BL1 & $8423.0^{\mathrm{b}}$ & $7.09 \times 10^{7}$ \\
\hline Formulation $\times$ Temperature & Mean $^{*}$ & Mean $^{\star *}$ \\
\hline BL2 $\left(37^{\circ} \mathrm{C}\right)$ & $22192.0^{\mathrm{a}}$ & $4.92 \times 10^{8}$ \\
BL3 $\left(45^{\circ} \mathrm{C}\right)$ & $17251.0^{\mathrm{ab}}$ & $2.98 \times 10^{8}$ \\
BL2 $\left(45^{\circ} \mathrm{C}\right)$ & $15071.0^{\mathrm{abc}}$ & $2.27 \times 10^{8}$ \\
BL3 $\left(37^{\circ} \mathrm{C}\right)$ & $13565.0^{\mathrm{abc}}$ & $1.84 \times 10^{8}$ \\
BL1 $\left(37^{\circ} \mathrm{C}\right)$ & $8518.0^{\mathrm{bc}}$ & $7.26 \times 10^{7}$ \\
BL1 $\left(45^{\circ} \mathrm{C}\right)$ & $8327.9^{\mathrm{c}}$ & $6.94 \times 10^{7}$ \\
\hline
\end{tabular}

${ }^{*}$ Media for square root transformed data; media followed by different letters are significantly different by Tukey's test at $95 \%$ confidence level. ${ }^{* *}$ Correspondent media at CFU.mL ${ }^{-1}$. 
showed the lowest counts, differing from BL2 and BL3 formulations. Nevertheless, all formulations were able to provide Bifidobacterium spp. counts higher than $10^{6} \mathrm{CFU} \cdot \mathrm{mL}^{-1}$. This enhanced viability of Bifidobacterium spp. could result from the presence of cheese whey and soybean hydrosoluble extract in the composition of lactic beverages. Cheese whey works as a source of peptides and amino acids when heattreatment is carried out during dairy beverage manufacture. Moreover, whey proteins are rich in sulfur-containing amino acids, which are liberated during the heat treatment, and these amino acids lower the redox potential of the medium, enhancing the growth of Bifidobacterium spp. (SHAH, 2000). Just the same, soybean hydrosoluble extract acts as a source of oligosaccharides (prebiotics), which stimulates the multiplication of bifidobacteria (SCHREZENMEIR; DE VRESE, 2001). The interaction formulation $\times$ fermentation temperature (Table 3) affected significantly the viability of Bifidobacterium spp. $(\mathrm{P}=0.0406)$. The highest counts were obtained for BL2 fermented at $37{ }^{\circ} \mathrm{C}$. Bifidobacterium spp. survived better in formulations containing $S$. thermophilus, and this could be explained by the fact that $S$. thermophilus acts as an oxygen scavenger, increasing the development of bifidobacteria (AKIN; GÜLER-AKIN, 2005).

\section{Conclusions}

The results of the present work showed that fermentation temperature had a significant consequence on viability of probiotic bacteria, with the highest viability obtained at $37^{\circ} \mathrm{C}$. L. acidophilus counts were affected by storage time, and this probiotic species was the most sensitive throughout the cold storage period. Physicochemical parameters have not exhibited drastic variations during storage, which indicates that the formulations of the lactic beverages studied were stable, and even the strongly proteolytic activity of probiotic bacteria was unable to affect the physicochemical stability during storage. Bifidobacterium spp. demonstrated significant survival ability, probably due to the presence of growth promoters in the composition of lactic beverages. The viability of all probiotic bacteria was above $10^{6} \mathrm{CFU} . \mathrm{mL}^{-1}$ when using fermentation temperature of $37^{\circ} \mathrm{C}$. The fermentation conditions for $S$. thermophilus EPS producing strain must be improved in order to enhance the EPS synthesis and rheological properties of the final product. Consequently, fermentation temperature of $37^{\circ} \mathrm{C}$ can be used to produce probiotic fermented lactic beverages, combined with the use of a starter culture, resulting in products with adequate level of viable cells for the beneficial effects of probiotic products. Furthermore, the inclusion of soybean hydrosoluble extract, a prebiotic source, resulted in a symbiotic product, with more advantages to the health of consumers.

\section{Acknowledgements}

This work was financially supported by FAPERGS ('Fundação de Amparo à Pesquisa do Estado do Rio Grande do Sul', Process $\mathrm{N}^{\circ}$ 05/17969). The authors are grateful to 'Danisco' and 'ISP Brasil', for providing some of the strains used in this work; to the friends in 'Núcleo de Alimentos' (UNIJUí), for their support, whenever necessary, in conducting experimental work; as well as to Ms. Iara Endruweit Battisti (DeFEM, UNIJUí) and Dr. Paulo José Ogliari ('Departamento de Informática e de Estatística', UFSC) for their useful recommendations concerning statistical analysis.

\section{References}

AKIN, M. S.; GÜLER-AKIN, M. B. Effect of different incubation temperatures on the microflora, chemical composition and sensory characteristics of bio-yogurt. Italian Journal of Food Science, v. 17, n. 1, p. 67-74, 2005.

ALMEIDA, K. E.; BONASSI, I. A.; ROÇA, R. O. Características Físicas e Químicas de Bebidas Lácteas Fermentadas e Preparadas com Soro de Queijo Minas Frescal. Ciência e Tecnologia de Alimentos, v. 2, n. 2, p. 187-192, 2001. http://dx.doi.org/10.1590/ S0101-20612001000200012

BEGLEY, M.; HILL, C.; GAHAN, C. G. M. Bile Salt Hydrolase Activity in Probiotics. Applied Environmental Microbiology, v. 72, p.1729-1738, 2006. PMid:16517616. PMCid:1393245. http://dx.doi. org/10.1128/AEM.72.3.1729-1738.2006

BEHRENS, J. H.; ROIG, S. M.; SILVA, M. A. A. P. Aspectos de Funcionalidade, de Rotulagem e de Aceitação de Extrato Hidrossolúvel de Soja Fermentado e Culturas Lácteas Probióticas. Boletim SBCTA, v. 34, n. 2, p. 99-106, 2001.

BROADBENT, J. R. et al. Review: Biochemistry, Genetics, and Applications of Exopolysaccharide Production in Streptococcus thermophilus. Journal Dairy Science, v. 86, p. 407-423, 2003. http:// dx.doi.org/10.3168/jds.S0022-0302(03)73619-4

CHAMPAGNE, C. P.; GARDNER, N. J. C; ROY, D. Challenges in the addition of probiotic cultures to foods. Critical Reviews in Food Science and Nutrition, v. 45, p. 61-84, 2005. http://dx.doi. org/10.1080/10408690590900144

CHOU, C.; HOU, J. Growth of bifidobacteria in soymilk and their survival in the fermented soymilk drink during storage. International Journal of Food Microbiology, v. 56, p. 113-121, 2000. http://dx.doi.org/10.1016/S0168-1605(99)00201-9

CORCORAN, B. M. et al. Survival of Probiotic Lactobacilli in Acidic Environments Is Enhanced in the Presence of Metabolizable Sugars. Applied Environmental Microbiology, v. 71, p. 3060-3067, 2005. PMid:15933002. PMCid:1151822. http://dx.doi.org/10.1128/ AEM.71.6.3060-3067.2005

DAVE, R. I.; SHAH, N. P. Evaluation of Media for Selective Enumeration of Streptococcus thermophilus, Lactobacillus delbrueckii ssp. bulgaricus, Lactobacillus acidophilus, and Bifidobacteria. Journal Dairy Science, v. 79, p. 1529-1536, 1996. http://dx.doi. org/10.3168/jds.S0022-0302(96)76513-X

DAVE, R. I.; SHAH, N. P. Effect of cystein on the viability of yoghurt and probiotic bacteria in yoghurts made with commercial starter culture. International Dairy Journal, v. 7, p. 537-545, 1997. http:// dx.doi.org/10.1016/S0958-6946(97)00053-8

DONKOR, O. N. et al. Effect of acidification on the activity of probiotics in yoghurt during cold storage. International Dairy Journal, v. 16, p. 1181-1189, 2006. http://dx.doi.org/10.1016/j.idairyj.2005.10.008

GOMES, A. M. P.; MALCATA, F. X. Bifidobacterium spp. and Lactobacillus acidophilus: biological, biochemical, technological and therapeutical properties relevant for use as probiotics. Trends in Food Science Technology, v. 10, p. 139-157, 1999. PMid:21299575. http://dx.doi.org/10.1016/S0924-2244(99)00033-3

HASHimOTO, E. M.; ANTUNES, L. A. F. Efeito do Tratamento Térmico e de Culturas Filantes nas Características Reológicas do 
Iogurte de Leite de Cabra. Ciência e Tecnologia de Alimentos, v. 15, n. 3, p. 255-261, 1995.

HOU, J. W.; YU, R. C.; CHOU, C. C. Changes in some componentes of soymilk during fermentation with bifidobacteria. Food Research International, v. 33. p. 393-397, 2000. http://dx.doi.org/10.1016/ S0963-9969(00)00061-2

INSTITUTO ADOLFO LUTZ - IAL. Métodos Químicos e Físicos para Análise de Alimentos. 3. ed. São Paulo: IAL, 1985. v. 1. Normas Analíticas do Instituto Adolfo Lutz.

ITSARANUWAT, P.; SHAL-HADDAD, K.; ROBINSON, R. K. The potential therapeutic benefits of consuming 'health-promoting' fermented dairy products: a brief update. International Journal of Dairy Technology, v. 56, n. 4, p. 203-210, 2003. http://dx.doi. org/10.1046/j.1471-0307.2003.00106.x

LAPIERRE, L.; UNDELAND, P.; COX, L. J. Lithium Chloride-Sodium Propionate Agar for the Enumeration of Bifidobacteria in Fermented Dairy Products. Journal of Dairy Science, v. 75, n. 5, p. 1192-1196, 1992. http://dx.doi.org/10.3168/jds.S0022-0302(92)77866-7

MACEDO, R. E. F, Desenvolvimento de bebida láctea fermentada a base de extrato hidrossolúvel de soja e soro de leite de búfala por cultura mista de Lactobacillus casei Shirota e Bifidobacterium adolescentis. 1997. 112 f. Dissertação (Mestrado em Tecnologia Química)-Universidade Federal do Paraná, Curitiba, 1997.

MARAGKOUDAKIS, P. A. et al. Probiotic potential of Lactobacillus strains isolated from dairy products. International Dairy Journal, v. 16, p. 189-199, 2006. http://dx.doi.org/10.1016/j. idairyj.2005.02.009

MATTILA-SANDHOLM, T. et al. Technological challenges for future probiotic foods. International Dairy Journal, v. 12, p.173-182, 2002. http://dx.doi.org/10.1016/S0958-6946(01)00099-1

MÖLLER, C.; DE VRESE, M. Review: Probiotic effects of selected acid bacteria. Milchwissenschaft, v. 59, n. 11/12, p. 597-601, 2004.

MONTGOMERY, D. C. Design and Analysis of Experiments. 5th ed. New York: John Wiley \& Sons, 2000.

MORTAZAVIAN, A. M. et al. Preliminary investigation of the combined effect of heat treatment and incubation temperature on the viability of the probiotic micro-organisms in freshly made yogurt. International Journal of Dairy Technology, v. 59, p. 8-11, 2006. http://dx.doi.org/10.1111/j.1471-0307.2006.00216.x

MORAES, R. M. et al. Efeito da desodorização nas características sensoriais de extratos hidrossolúveis de soja obtidos por diferentes processos tecnológicos. Ciência e Tecnologia de Alimentos, v. 26, p. 46 -51 2006. http://dx.doi.org/10.1590/S010120612006000100008

ORDÓÑEZ, J. A. et al. Tecnologia de Alimentos - Alimentos de Origem Animal. Tradução de Fátima Murad. Porto Alegre: Artmed, 2005. v. 2, 279 p.

OTIENO, D. O.; ASHTON, J. F.; SHAH, N. P. Stability of $\beta$-glucosidase Activity Produced by Bifidobacterium and Lactobacillus spp. in Fermented Soymilk During Processing and Storage. Journal Food Science, v. 70, p. M236-M241, 2005. http://dx.doi. org/10.1111/j.1365-2621.2005.tb07194.x

PRUDENCIO, E. S.; BENEDET, H. D. Aproveitamento do Soro de Queijo na Obtenção do Extrato Hidrossolúvel de Soja. Ciência e Tecnologia de Alimentos, v. 19, n. 1, p. 97-101, 1999.

RIBEIRO, P. E.; MORAES, C. A. M.; ROIG, M. S. Utilização de misturas de extrato hidrossolúvel de soja com leite de vaca para fabricação de iogurte. Revista do Instituto de Laticínios Cândido Tostes, v. 42, p. 9-14, 1987.

RUAS-MADIEDO, P.; ALTING, A. C.; ZOON, P. Effect of exopolysaccharides and proteolytic activity of Lactococcus lactis subsp. cremoris strains on the viscosity and structure of fermented milks. International Dairy Journal, v. 15, n. 2, p. 155-164, 2005. http://dx.doi.org/10.1016/j.idairyj.2004.05.009

RUAS-MADIEDO, P.; REYES-GAVILÁN, C. G. D. L. Methods for the Screening, Isolation, and Characterization of Exopolysaccharides Produced by Lactic Acid Bacteria. Journal Dairy Science, v. 88, n. 3, p. 843-856, 2005. http://dx.doi.org/10.3168/jds.S00220302(05)72750-8

SANDERS, M. E.; KLAENHAMMER, T. R. The Scientific Basis of Lactobacillus acidophilus NCFM Functionality as a Probiotic. Journal of Dairy Science, v. 84, n. 2, p. 319-331, 2001. http://dx.doi. org/10.3168/jds.S0022-0302(01)74481-5

SCHILLINGER, U.; GUIGAS, C.; HOLZAPFEL, H. In vitro adherence and other properties of lactobacilli used in probiotic yoghurt-like products. International Dairy Journal, v. 15, n. 12, p. 1289-1297, 2005. http://dx.doi.org/10.1016/j.idairyj.2004.12.008

SCHREZENMEIR, J.; DE VRESE, M. Probiotics, prebiotics, and symbiotics - approaching a definition. American Journal of Clinical Nutrition, v. 73, n. 2, p. 361S-364S, 2001.

SHAH, N. P. Probiotic Bacteria: Selective Enumeration and Survival in Dairy Foods. Jornal Dairy Science, v. 83, n. 4, p. 894-907, 2000. http://dx.doi.org/10.3168/jds.S0022-0302(00)74953-8

SVENSSON, M. et al. Metabolically Improved Exopolysaccharide Production by Streptococcus thermophilus and Its Influence on the Rheological Properties of Fermented Milk. Appllied Environmental Microbiology, v. 71, n. 10, p. 6398-6400, 2005. PMid:16204566. PMCid:1265931. http://dx.doi.org/10.1128/ AEM.71.10.6398-6400.2005

TALWALKAR, A.; KALLASAPATHY, K. A review of oxygen toxicity in probiotic yogurts: influence on the survival of probiotic bacteria and protective techniques. Comprehensive Reviews in Food Science and Food Safety, v. 3, p. 117-124, 2003. http://dx.doi. org/10.1111/j.1541-4337.2004.tb00061.x

TALWALKAR, A.; KAILASAPATHY, K. Comparison of selective and differential media for the accurate enumeration of strains of Lactobacillus acidophilus, Bifidobacterium spp. and Lactobacillus casei complex from commercial yoghurts. International Dairy Journal, v. 14, n. 2, p. 143-149, 2004. http://dx.doi.org/10.1016/ S0958-6946(03)00172-9

TAMIME, A. Y.; MARSHALL, V. M.; ROBINSON, R. K. Microbiological and technical aspects of milk fermented by bifidobacteria. Journal of Dairy Science, v. 62, p. 151-187, 1995.

TAMIME, A. Y. Review: Fermented milks: a historical food with modern applications. European Journal of Clinical Nutrition, v. 56, p. S2-S15, 2002. Supplement 4. PMid:12556941. http://dx.doi. org/10.1038/sj.ejcn.1601657

TEBALDI, V. M. R. Elaboração de bebida láctica de soro de ricota e extrato solúvel de soja. 2005. 79 f. Dissertação (Mestrado em Microbiologia Agrícola)-Universidade Federal de Lavras, Lavras, 2005.

THAMER, K. G.; PENNA, A. L. B. Caracterização de Bebidas Lácteas Funcionais Fermentadas por Probióticos e Acrescidas de Prebiótico. Ciência e Tecnologia de Alimentos, v. 26, n. 3, p. 589-595, 2006. http://dx.doi.org/10.1590/S0101-20612006000300017

VINDEROLA, C. G.; BAILO, N.; REINHEIMER, J. A. Survival of probiotic microflora in Argentinian yoghurts during refrigerated storage. Food Research International, v. 33, n. 2, p. 97-102, 2000. http://dx.doi.org/10.1016/S0963-9969(00)00011-9

VINDEROLA, C. G.; MOCCHIUTTI, P.; REINHEIMER, J. A. Interactions among lactic acid starter and probiotic bacteria used for fermented dairy products. Jounal of Dairy Science, v. 85 , n. 4 , p. $721-729,2002$. http://dx.doi.org/10.3168/jds.S00220302(02)74129-5 
VINDEROLA, C. G.; REINHEIMER, J. A. Culture media for the enumeration of Bifidobacterium bifidum and Lactobacillus acidophilus in the presence of yoghurt bacteria. International Dairy Journal, v. 9, n. 8, p. 497-505, 1999. http://dx.doi.org/10.1016/ S0958-6946(99)00120-X

WANG, Y.-C.; YU, R.-C.; CHOU, C.-C. Viability of latic acid bacteria and bifidobacteria in fermented soymilk after drying, subsequent rehydration and storage. International Journal of Food Microbiology, v. 93, p. 209-217, 2004. PMid:15135959. http:// dx.doi.org/10.1016/j.ijfoodmicro.2003.12.001

ZACARCHENCO, P. B. Leites fermentados por Streptococcus thermophilus adicionados de Lactobacillus. acidophilus e Bifidobacterium longum: Isolamento diferencial dos microrganismos, multiplicação em diferentes condições e efeitos nas características sensoriais dos leites fermentados naturais ou modificados. 2004. Tese (Doutorado em Tecnologia de Alimentos)Universidade Estadual de Campinas, Campinas, 2004.

ZACARCHENCO, P. B.; MASSAGUER-ROIG, S. Avaliação Sensorial, Microbiológica e de Pós-Acidificação Durante a Vida-de-Prateleira de Leites Fermentados Contendo Streptococcus thermophilus, Bifidobacterium longum e Lactobacillus acidophilus. Ciência e Tecnologia de Alimentos, v. 24, n. 4, p. 674-679, 2004. http://dx.doi. org/10.1590/S0101-20612004000400033 